\title{
An improved system for competent cell preparation and high efficiency plasmid transformation using different Escherichia coli strains
}

\author{
China-UK HUST-Res Crop Genetics Engineering and Genomics Joint Laboratory \\ School of Life Science and Technology \\ Huazhong University of Science and Technology \\ Wuhan, 4300074, China \\ Tel: 862787556214 \\ Fax: 862787548885 \\ E-mail: tuzhiming@mail.hust.edu.cn
}

Guangyuan $\mathrm{He}^{*}$

China-UK HUST-RRes Crop Genetics Engineering and Genomics Joint Laboratory School of Life Science and Technology

Huazhong University of Science and Technology

Wuhan, 4300074, China

Tel: 862787556214

Fax: 852787548885

E-mail: guang.he@bbsrc.ac.uk

Kexiu X. Li

China-UK HUST-RRes Crop Genetics Engineering and Genomics Joint Laboratory School of Life Science and Technology

Huazhong University of Science and Technology

Wuhan, 4300074, China

Tel: 862787556214

Fax: 862787548885

\section{Mingjie J. Chen}

China-UK HUST-RRes Crop Genetics Engineering and Genomics Joint Laboratory School of Life Science and Technology

Huazhong University of Science and Technology

Wuhan, 4300074, China

Tel: 862787556214

Fax: 862787548885

\section{Junli Chang}

China-UK HUST-RRes Crop Genetics Engineering and Genomics Joint Laboratory School of Life Science and Technology

Huazhong University of Science and Technology

Wuhan, 4300074, China

Tel: 862787556214

Fax: 862787548885

\section{Ling Chen}

China-UK HUST-RRes Crop Genetics Engineering and Genomics Joint Laboratory School of Life Science and Technology

Huazhong University of Science and Technology

Wuhan, 4300074, China

Tel: 862787556214

Fax: 862787548885

\section{Qing Yao}

China-UK HUST-RRes Crop Genetics Engineering and Genomics Joint Laboratory School of Life Science and Technology

Huazhong University of Science and Technology

Wuhan, 4300074, China

Tel: 862787556214

Fax: 862787548885

\section{Dongping P. Liu}

China-UK HUST-RRes Crop Genetics Engineering and Genomics Joint Laboratory School of Life Science and Technology

Huazhong University of Science and Technology 
Wuhan, 4300074, China

Tel: 862787556214

Fax: 862787548885

\section{Huan Ye}

China-UK HUST-RRes Crop Genetics Engineering and Genomics Joint Laboratory

School of Life Science and Technology

Huazhong University of Science and Technology

Wuhan, 4300074, China

Tel: 862787556214

Fax: 862787548885

Jiantao Shi

China-UK HUST-RRes Crop Genetics Engineering and Genomics Joint Laboratory School of Life Science and Technology

Huazhong University of Science and Technology

Wuhan, 4300074, China

Tel: 862787556214

Fax: 862787548885

\section{Xuqian Wu}

China-UK HUST-RRes Crop Genetics Engineering and Genomics Joint Laboratory School of Life Science and Technology

Huazhong University of Science and Technology

Wuhan, 4300074, China

Tel: 862787556214

Fax: 862787548885

Website: http://www.hust.edu.cn

Financial support: States Development Plan of High Technology ("863" Plan).

Keywords: competent cells, E. coli, plasmid, storage, transformation.

Abbreviations: cfu: Colony Forming Units;

TB: transformation buffer of $\mathrm{CaCl}_{2}$ solution.

This paper describes an efficient bacterial transformation system that was established for the preparation of competent cells, plasmid preparation, and for the storage in bacterial stocks in our laboratory. Using this method, a number of different plasmids have been amplified for further experiments. Competent cells for bacterial transformation were prepared by the calcium chloride method with an optimum concentration of $75 \mathrm{mM}$. Three different strains of Escherichia coli that were tested are DH5a, TG1 and XL1 blue, and the most efficient strain being XL1 blue. The optimal optical density $\left(\mathrm{OD}_{600}\right)$ range for competent cell preparation varied for each of the strains investigated, and for XL1 blue it was 0.15-0.45; for TG1 it was 0.2-0.5; and for DH5 $\alpha$ it was 0.145-0.45. The storage time of competent cells and its correlation to transformation efficiency has been studied, and the result showed that competent cells can be stored at $20^{\circ} \mathrm{C}$ for 7 days and at $-7^{\circ} \mathrm{C}$ for 15 days. Three critical alterations to previous methods have been made, which are the changing of the normal $\mathrm{CaCl}_{2}$ solution to $\mathrm{TB}$ solution, the changing of the medium from LB to S.O.C., and addition of DMSO or $\mathbf{P E G}_{\mathbf{8 0 0 0}}$ during transformation of competent cells with plasmids. Changing the medium from LB to S.O.C., resulted in much faster growth of transformants, and the transformation efficiency was increased. Addition of DMSO or PEG $_{8000}$ raised transformation efficiencies by 100-300 fold. Our improved bacterial transformation system can raise the transformation efficiency about $10^{3}$ times, making it becoming a highly efficient bacterial transformation system.

Plasmid transformation into bacterial competent cells is a key technique in molecular cloning. In early 1970's Cohen (Cohen et al. 1973) successfully transformed R-factor and recombinant plasmids into $E$. coli cells using a calcium chloride method. Since that time this method has been widely used due to its convenience. An alternative

\footnotetext{
* Corresponding author
} 
transformation method used is electroporation which results in a higher transformation efficiencies of up to $10^{9}-10^{10}$

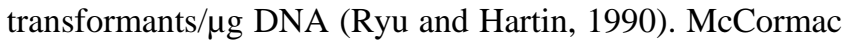
(McCormac et al. 1998) published a simple method for the production of highly competent cells of Agrobacterium tunrefaciers/rhizobium for transformation via electroporation. Okamoto (Okamoto et al. 1997) also reported high efficiency transformation of Bacillus brevis by electroporation, however, special equipment is required for electroporation that many laboratories cannot provide. Tsen has found certain strains of $E$. coli can incorporate extracellular plasmids into cytoplasm 'naturally' at low frequencies (Tsen et al. 2002). Kurien and Scofield have described a quick and moderately efficient method of bacterial colony transformation (Kurien and Scofield, 1995). More recently, Chen has proposed an alternative convenient and rapid method for the genetic transformation of $E$. coli with plasmids. By mixing the recipient cells and plasmid DNA and spreading them directly on selective medium plates containing $\mathrm{Ca}^{2+}$, the so-called 'plate transformation' could achieve almost the same transformation efficiency as the classical transformation method with calcium, yet the whole protocol takes only approximately 2 min (Chen et al 2001). Based on this method, we have established an efficient system using $E$. coli competent cells for transformation plasmids. Plasmids then can be stored as bacterial stocks in our China-UK joint laboratory, which allows amplification of plasmids for future experiments.

\section{MATERIALS}

\section{Bacterial strains}

The E. coli DH5 $\alpha$ and E. coli TG1 were from Wuhan University (China); E. coli XL1 blue was from Hubei University (China) and Rothamsted Research (UK).

\section{Plasmids}

The following plasmids used in our laboratory were obtained from various sources and stored in our laboratory:

Marker gene plasmids. pUC18, pDE4, pDE108, pDE 110, pCal-gus, pCal-neo, pAct1D-gus, pAHC 25, pRT99gus, PRT99, pAHC20, pUGFP, pCX GFP.

HMW glutenin plasmids. p1Ax1, p1Dx5, p1Dy10, p1Dy12, pHMW-gus, pHMW-nos, pGAD2.

\section{Media for bacterial growth}

LB medium. 10 g/L Bacto -Tryptone, 5 g/L Bacto -Yeast Extract, $5 \mathrm{~g} / \mathrm{L} \mathrm{NaCl}$, adjust the $\mathrm{pH}$ to 7.5 with $\mathrm{NaOH}$ autoclave to sterilize. Allow the auto-claved medium to cool to $55^{\circ} \mathrm{C}$ and add ampicillin (final concentration 100 $\mu \mathrm{g} / \mathrm{ml})$. For LB plates, 1.5\% Bacto-agar (15 g/L) was added prior to autoclaving.
S.O.C. medium. 2\% Tryptone (bacto), $0.5 \%$ Yeast Extract, $10 \mathrm{mM} \mathrm{NaCl}, 2.5 \mathrm{mM} \mathrm{MgCl}, 10 \mathrm{mM} \mathrm{MgSO} 4,20$ mM glucose.

\section{Buffer and additional solutions}

TB $\left(\mathrm{CaCl}_{2}\right)$ solution (Inoue et al. 1990). $10 \mathrm{mM}$ Pipes, $55 \mathrm{mM} \mathrm{MnCl}_{2}, 15 \mathrm{mM} \mathrm{CaCl}_{2}, 250 \mathrm{mM} \mathrm{KCl}$. (PIPES 3.021 g/l, $\mathrm{CaCl}_{2} \cdot 2 \mathrm{H}_{2} \mathrm{O} 2.205 \mathrm{~g} / \mathrm{l}, \mathrm{KCl} 18.637 \mathrm{~g} / \mathrm{l}, \mathrm{MnCl}_{2} \cdot 4 \mathrm{H}_{2} \mathrm{O}$ $10.885 \mathrm{~g} / \mathrm{l})$. All the components except for $\mathrm{MnCl}_{2}$ were mixed and the $\mathrm{pH}$ was adjusted to 6.7 with $\mathrm{KOH}$. Then, $\mathrm{MnCl}_{2}$ was dissolved, the solution was sterilized by filtration through a prerinsed $0.45 \mu \mathrm{m}$ filter unit and stored at $4^{\circ} \mathrm{C}$, all salts were added as solids, always kept and used in cold.

DMSO bought from ALPHA Biotechnologies Company, LTD (SigmaD5879).

PEG $_{8000}$ are bought from Sino-American Company (Wuhan, China), $\mathrm{PEG}_{8000}(40 \%)$ solution stored at $-20^{\circ} \mathrm{C}$.

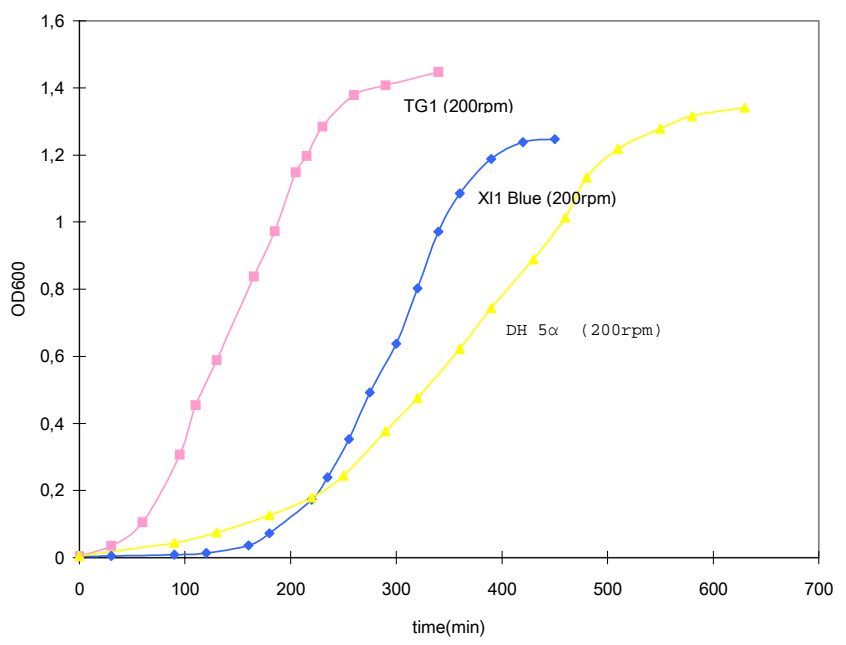

Figure 1. Growth curve of XL1 blue; TG1, and DH5a.

\section{METHODS}

\section{Preparation of competent cell}

There are two main methods for transformation of competent bacterial cells, the calcium chloride and the electroporation method (Dargert et al. 1979; Okamoto et al. 1997; Topcu, 2000). We choose the calcium chloride method.

Calcium chloride method. A $10 \mu \mathrm{l}$ glycerol stock of an E. coli strain containing no plasmids was allowed to thaw at room temperature and added to $40 \mathrm{ml}$ of liquid S.O.C. media. This culture was incubated at $37^{\circ} \mathrm{C}$ for $1 \mathrm{hr}$, then transferred to an incubator-shaker, at $37^{\circ} \mathrm{C}$, shaking at 200 rpm for 2-3 hrs until an $\mathrm{OD}_{600}$ of 0.2-0.4 was reached. The optimum $\mathrm{OD}_{600}$ for the different bacterial strains varied. 
Table1. Transformation efficiency of plasmid DNA to different E. coli strains (Average).

\begin{tabular}{|c|c|c|c|c|c|c|c|c|c|}
\hline & \multicolumn{2}{|c|}{$\begin{array}{c}\text { XL1 blue E. coli } \\
\text { strains }\end{array}$} & \multicolumn{4}{c|}{ DH5a E. coli strains } & \multicolumn{3}{c|}{ TG1 E. coli strains } \\
\hline plasmid & $\begin{array}{c}\text { Normal } \\
\text { method } \\
\text { (Sambrook, } \\
\text { 1989) }\end{array}$ & $\begin{array}{c}\text { Quick } \\
\text { method } \\
\text { (Chen, } \\
\mathbf{2 0 0 1 )}\end{array}$ & $\begin{array}{c}\text { This } \\
\text { improved } \\
\text { method }\end{array}$ & $\begin{array}{c}\text { Normal } \\
\text { method } \\
\text { (Sambrook } \\
\text { 1989) }\end{array}$ & $\begin{array}{c}\text { Quick } \\
\text { method } \\
\text { (Chen, } \\
\mathbf{2 0 0 1 )}\end{array}$ & $\begin{array}{c}\text { This } \\
\text { improved } \\
\text { method }\end{array}$ & $\begin{array}{c}\text { Normal } \\
\text { method } \\
\text { (Sambrook } \\
\text { 1989) }\end{array}$ & $\begin{array}{c}\text { Quick } \\
\text { method } \\
\text { (Chen, } \\
\text { 2001) }\end{array}$ & $\begin{array}{c}\text { This } \\
\text { improved } \\
\text { method }\end{array}$ \\
\hline pUC18 & $6.51 \times 10^{6}$ & $7.1 \times 10^{5}$ & $8.18 \times 10^{8}$ & $2.31 \times 10^{6}$ & $3.5 \times 10^{5}$ & $4.15 \times 10^{8}$ & $2.01 \times 10^{6}$ & $3.8 \times 10^{5}$ & $4.5 \times 10^{8}$ \\
\hline pUGFP & $7.79 \times 10^{6}$ & $6.7 \times 10^{5}$ & $8.85 \times 10^{8}$ & $1.66 \times 10^{6}$ & $3.2 \times 10^{5}$ & $2.63 \times 10^{8}$ & $1.25 \times 10^{6}$ & $2.2 \times 10^{5}$ & $4.72 \times 10^{8}$ \\
\hline pAHC25 & $6.86 \times 10^{6}$ & $7.8 \times 10^{5}$ & $9.09 \times 10^{8}$ & $1.56 \times 10^{6}$ & $2.7 \times 10^{5}$ & $4.13 \times 10^{8}$ & $1.46 \times 10^{6}$ & $2.9 \times 10^{5}$ & $5.39 \times 10^{8}$ \\
\hline p1Ax1 & $7.13 \times 10^{6}$ & $6.4 \times 10^{5}$ & $8.6 \times 10^{8}$ & $1.25 \times 10^{6}$ & $2.3 \times 10^{5}$ & $4.52 \times 10^{8}$ & $1.08 \times 10^{6}$ & $2.7 \times 10^{5}$ & $4.26 \times 10^{8}$ \\
\hline p1Dx5 & $7.09 \times 10^{6}$ & $6.98 \times 10^{5}$ & $8.9 \times 10^{8}$ & $1.31 \times 10^{6}$ & $2.08 \times 10^{5}$ & $3.99 \times 10^{8}$ & $1.21 \times 10^{6}$ & $2.08 \times 10^{5}$ & $4.19 \times 10^{8}$ \\
\hline p1Dy10 & $8.17 \times 10^{6}$ & $6.75 \times 10^{5}$ & $7.8 \times 10^{8}$ & $1.20 \times 10^{6}$ & $1.97 \times 10^{5}$ & $3.56 \times 10^{8}$ & $1.31 \times 10^{6}$ & $1.97 \times 10^{5}$ & $3.25 \times 10^{8}$ \\
\hline
\end{tabular}

Determination of their early log phase is important. The cells were pelleted by centrifugation at $8000 \mathrm{rpm}$ for $1 \mathrm{~min}$ at $4^{\circ} \mathrm{C}$, then resuspended in one-half volume $(20 \mathrm{ml})$ of sterile cold TB $\left(\mathrm{CaCl}_{2}\right)$ solution, and incubated on ice for 25 min. After another centrifugation step as above, the resulting cell pellet was resuspended in one-tenth volume (4 $\mathrm{ml})$ of sterile cold TB $\left(\mathrm{CaCl}_{2}\right)$ solution to yield the final competent cell suspension. Competent cells can be stored at $4^{\circ} \mathrm{C}$ for up to 3 days.

Preparation of competent cells for storage as glycerol stocks. Transfer $1.6 \mathrm{ml}$ of the competent cell suspension to sterile cryo-storage tubes, and add $0.4 \mathrm{ml}$ of sterile $100 \%$ glycerol to give a final concentration of $20 \%$ glycerol, and then mix together. The glycerol stocks are placed at $-4^{\circ} \mathrm{C},-20^{\circ} \mathrm{C}$ and $-70^{\circ} \mathrm{C}$ separately for later use.

\section{Bacterial transformation}

Plasmid transformation and antibiotic selection. Calcium chloride treatment of bacterial cells produces competent cells that will take up DNA following a heat shock step. DNA molecules, i.e. plasmids, which are introduced by this method, will then be replicated in the bacterial host cells. To aid the bacterial cells' recovery, the cells are incubated briefly with non-selective growth medium following the heat shock treatment. However, due to the low percentage of bacterial cells that have been transformed with the plasmid and the potential for the plasmid not to propagate itself in all daughter cells, it is necessary to select for bacterial cells that contain the plasmid. This is commonly performed using antibiotic selection.

E. coli strains such as $\mathrm{XL}_{1}$ blue, $\mathrm{DH} 5 \alpha$ and $\mathrm{TG}_{1}$ are sensitive to common antibiotics such as ampicillin. Plasmids used for the cloning and manipulating of DNA have been engineered therefore to harbour genes for antibiotic resistance to, for example, ampicillin. Thus, if following the transformation procedure, bacteria are plated onto media containing ampicillin, only bacteria that possess the plasmid DNA will have the ability to metabolize ampicillin and form colonies. In this way, bacterial cells containing plasmid DNA can be selected.

\section{Bacterial transformation protocol of our laboratory.}

a) Pre-heat plates of solid S.O.C. and S.O.C. ampicillin (final concentration $100 \mu \mathrm{g} / \mathrm{ml}$ ) at $37^{\circ} \mathrm{C}$ for $1 \mathrm{hr}$.

b) Take $100 \mu \mathrm{l}$ competent cells and add $1 \mu \mathrm{g} / \mu \mathrm{l}$ plasmid DNA $0.5 \mu l$.

c) Add DMSO or PEG 8000 (40\%) $1 \mu \mathrm{l}$.

d) Incubate on ice for $30 \mathrm{~min}$.

e) Heat shock at $42^{\circ} \mathrm{C}$ for $90 \mathrm{~s}$. (For an even quicker transformation method, this step can be neglect or omitted).

f) Incubate on ice for $2 \mathrm{~min}$.

g) Add $400 \mu \mathrm{l}$ liquid S.O.C. medium.

h) Incubate at $37^{\circ} \mathrm{C}$ for $45 \mathrm{~min}$ in an incubate-shaker.

i) Spread half of the mix (50 $\mu$ l) onto a pre-heated plate with ampicillin, and the other half onto a control plate without ampicillin.

j) Incubate plates at $37^{\circ} \mathrm{C}$ over night for S.O.C. medium (12-16 hrs).

\section{RESULTS}

Using cells in the early log phase of growth is an important factor for preparation of competent cells. By studying growth curves, the optimum $\mathrm{OD}_{600}$ range can be determined. The growth curves of three different $E$.coli strains are shown in Figure 1. Our experiment shows that the optimal optical density $\left(\mathrm{OD}_{600}\right)$ range for competent cell preparation varied for each of the strains investigated (Figure 2), and for XL1 blue it was 0.15-0.45; for TG1 it was 0.2-0.5; and for $\mathrm{DH} 5 \alpha$ it was 0.145-0.45. Another important factor is the concentration of $\mathrm{CaCl}_{2}$. Although 50-100 mM calcium chloride can be used, but $75 \mathrm{mM}$ $\mathrm{CaCl}_{2}$ in $\mathrm{TB}$ solution was found to be the optimum concentration.

\section{Calculation of transformation efficiency (colony forming units [cfu])}


Transformation efficiency is defined as the number of cfu produced by $1 \mu \mathrm{g}$ of plasmid DNA, and is measured by performing a control transformation reaction using a known quantity of DNA, then calculating the number of cfu formed per microgram DNA.

\section{Equation for transformation efficiency (cfu/ $\mu \mathrm{g})$}

Transformant $\mathrm{cfu}=$ No. of bacteria colonies $\times$ dilution ratio $\times$ original transformation volume/plated volume

Example: If 21 colonies are observed on the plate, before plating, the transformed competent cells were diluted 10000 times, and the original transformation volume was $100 \mu \mathrm{l}$, $50 \mu \mathrm{l}$ was used to plate, then transformant cfu is:

$21 \times 10000 \times 100 / 50=4.2 \times 10^{5}$

Transformation efficiency $=$ Transformant $\mathrm{cfu} /$ plasmid DNA $(\mu \mathrm{g})$.

If the plasmid DNA was added $0.5 \mu \mathrm{l}(1 \mu \mathrm{g} / \mu \mathrm{l})$, the transformation efficiency $=4.2 \times 10^{5} / 0.5=8.4 \times 10^{5}$ cfu/ $\mu g$.

The transformation efficiency per microgram plasmid DNA to different bacterial strains is shown in Table 1. These are the average data of 6 repeats, which shows the most efficient strain being XL1 blue. Our improved method can increase transformation efficiency approximately 1000 fold more than normal method (Sambrook et al. 1989), but Quick method (Chen et al. 2001) decrease transformation efficiency approximately 60-150 fold less than normal method (Sambrook et al. 1989).

The transformation efficiency of different plasmids by using different methods to different bacterial strains is shown in Figure 3. We used pUC18 to set up our system, and used pUGFP, pAHC25, p1Ax1, p1Dx5, p1Dy10 to test our system, then calculated the average transformation efficiency, and got the Figure 3 . Then we use this improved method to amplify other plasmids such as pDE 110, pRT99,
pAHC20, pABPIgus, pRT101, pRTL2, pCX GFP, p1Dy12, pJD2, pHMW-gus, pHMW-nos, pGAD2, pGAD12 and so on, which shows that our improved method can increase transformation efficiency much more than normal method (Sambrook et al. 1989), but Quick method (Chen et al. 2001) decrease transformation efficiency obviously compared to normal method (Sambrook et al. 1989).

\section{Effect of competent cell storage time at different temperature on transformation efficiencies}

The effect of competent cell storage time at different temperature on transformation efficiencies has been studied. We use pAHC25 plasmid to transform XL1 blue competent cells, which have been stored at $-4^{\circ} \mathrm{C},-20^{\circ} \mathrm{C}$, and $-70^{\circ} \mathrm{C}$ separately for $1 \mathrm{hr}, 1$ night, 1 day, 2 days, 3 days, 5 days, 7 days, 10 days, 15 days and 20 days. Normal transformation method has been used. The final result is showed in Figure 4. The effect of competent cell storage time at $-20^{\circ} \mathrm{C}$ on transformation efficiency shows XL1 blue competent cells can be stored at $-20^{\circ} \mathrm{C}$ and used in $1 \mathrm{hr}$ to 7 days without obvious decreasing of transformation efficiency, on the contrary, the transformation efficiency increased from 3 days to 7 days, then decreased gradually. Figure 4 shows the effect of competent cell storage time at different temperatures on the transformation efficiency, Which shows competent cells can be stored at $-20^{\circ} \mathrm{C}$ for 7 days and at $-70^{\circ} \mathrm{C}$ for 15 days without losing their competency apparently.

\section{DISCUSSION}

Transformation efficiency is very important in molecular cloning experiments, and can be affected by many factors. Takahashi have reported a simple method of plasmid transformation of $E$. coli by rapid freezing (Takahashi et al. 1992). The most important being that the bacterial cells must in their early logarithmic growth period, Ryu and other authors have pointed out the importance of the early log phase for transformation (Ryu and Hartin, 1990). Bacteria that are able to take up DNA are called "competent" and competency can be induced by treatment

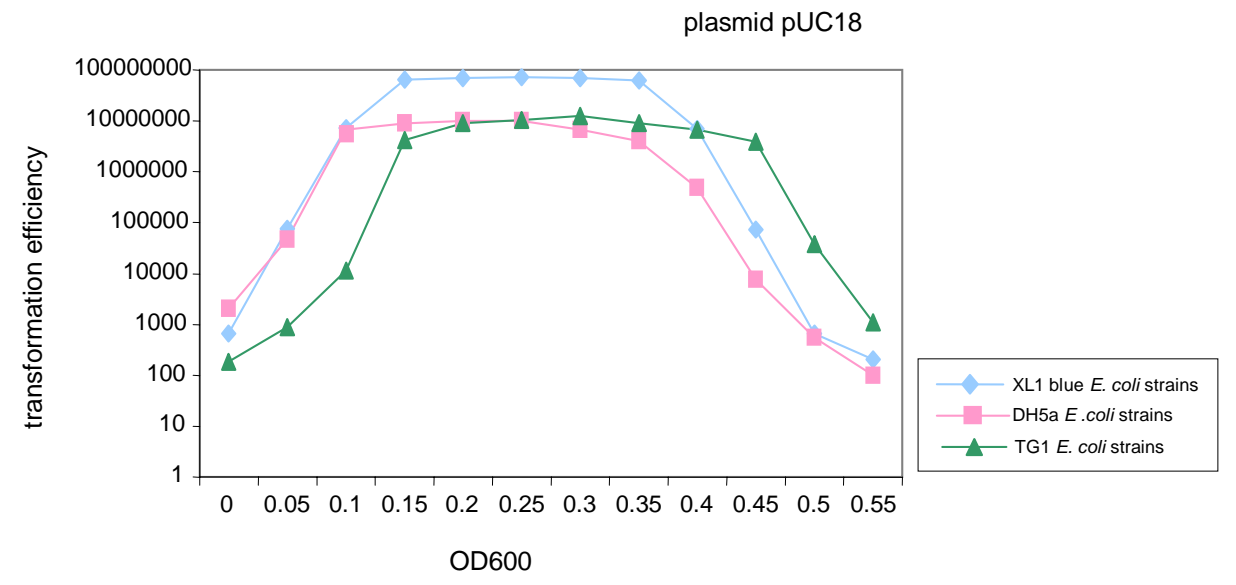

Figure 2. The optimal optical density $\left(\mathrm{OD}_{600}\right)$ range for competent cell preparation for three different strains of Escherichia coli. 117 
with calcium chloride in the early log phase of growth. The bacterial cell membrane is permeable to chloride ions, but is non-permeable to calcium ions. As the chloride ions enter the cell, water molecules accompany the charged particle. This influx of water causes the cells to swell and is necessary for the uptake of DNA; the exact mechanism of this uptake is unknown. Our experiments have shown that different strains of $E$. coli have different growth characteristics, such as E. coli: XL1 blue, TG1 and DH5 $\alpha$, therefore, the optimal $\mathrm{OD}_{600}$ range to use for preparation of competent cells varies: For XL1 blue this is $0.15-0.45$; for TG1 0.2-0.5; and for DH5 $\alpha$ 0.145-0.45. Competent cells prepared from the overgrowth or undergrowth bacterial cultures outside these optimal $\mathrm{OD}_{600}$ range will have reduced or no transformation capacity. In our laboratory, XL1 blue was found to have the highest transformation efficiency; therefore it is more commonly used. Bacteria for preparation of competent cells would routinely be cultured to $\mathrm{OD}_{600}=0.2-0.4$.

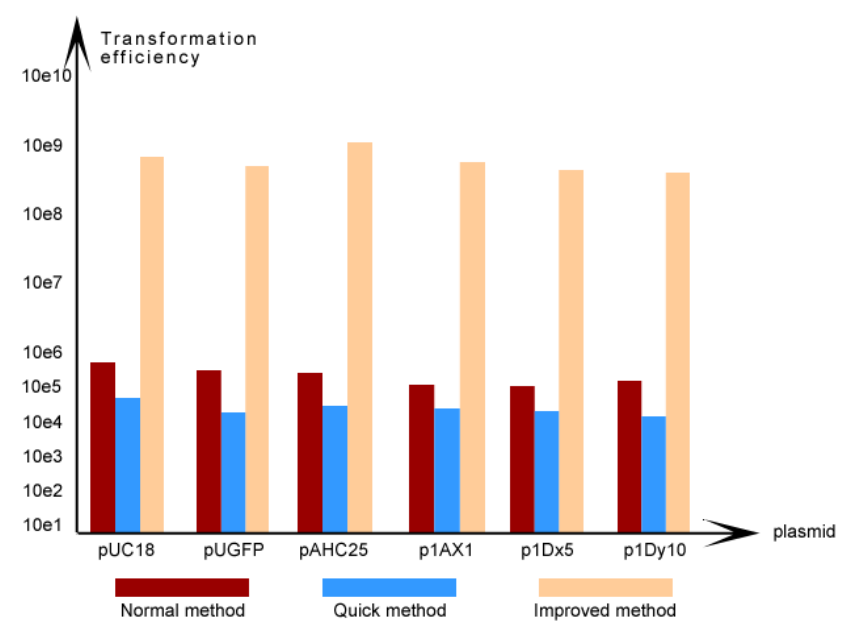

Figure 3. Transformation efficiency of different plasmids by using different method

A second factor, which can have an impact on the transformation efficiency, is that the competent cells must be maintained in cold environment, both during storage and in use. Dargert (Dargert and Ehrlich, 1979) reported that competent cells could be stored at $4^{\circ} \mathrm{C}$ in Calcium chloride for $24-48 \mathrm{hrs}$. In the prime $12-24 \mathrm{hrs}$, the transformation efficiency rise 3-5 times, then reduces to average level. Our experiments show that competent cells can be stored at $70^{\circ} \mathrm{C}$ for 15 days without obviously reducing their transformation capacity. However, if the competent cells are stored at $-20^{\circ} \mathrm{C}$, the highest transformation efficiencies appear at 2-7 days. But if the storage time was over 7 days, the transformation efficiency was dramatically reduced. If competent cells were stored at $4^{\circ} \mathrm{C}$, they will lose their competency in only 3 days. Competent cell cannot be stored long term under liquid $\mathrm{N}_{2}$ and cannot be defrosted more than once.
Another important factor is the concentration of $\mathrm{CaCl}_{2}$. Although 50-100 mM calcium chloride can be used, but 75 $\mathrm{mM} \mathrm{CaCl} \mathrm{C}_{2}$ in TB solution was found to be the optimum concentration. Brian and Heler (Brian and Heler, 1996) first used TFB as a substitute for the traditional $\mathrm{CaCl}_{2}$ solution. We used TB solution, which increased transformation efficiencies more than 100 fold. Using the traditional $\mathrm{CaCl}_{2}$ method at $37^{\circ} \mathrm{C}$, the no. of transformants $/ \mu \mathrm{g}$ plasmid DNA was $1 \times 10^{5} \sim 10 \times 10^{5}$. Using TB under the same conditions resulted in the no. transformants/ $\mu$ g plasmid DNA of $1 \times 10^{7} \sim 9 \times 10^{7}$.

The addition of DMSO or PEG $_{8000}$ during bacterial transformation can also affect transformation efficiency. Hanahan (Hanahan et al. 1991) found the addition of DMSO greatly increased the transformation efficiency. Similarly, incubation of competent cells and plasmid DNA in a solution of polyethylene glycol/Calcium chloride $\left(\mathrm{PEG} / \mathrm{CaCl}_{2}\right)$ following by a brief incubation and heat shock resulted in efficient uptake of DNA (Kurien and Scofield, 1995). Our experiments show that addition of DMSO or $\mathrm{PEG}_{8000}$ during transformation process can give a transformation efficiency of 100-300 fold higher than the Cohen's method.

The bacterial culture medium can also affect the transformation efficiency. Jessee (Fierro, 2004; Maeda et al. 2004) suggested S.O.C. medium for growth of bacteria for preparation of competent cells. S.O.C. is a richer medium than LB medium, which therefore results in faster growth of bacteria; not only can transformants be observed sooner in S.O.C. medium after 12 hrs as opposed to 24 hrs in LB medium, but the transformation efficiency is much higher; S.O.C. giving 10-30 times higher efficiency than LB.

It is known that the effect of calcium chloride treatment can be enhanced if followed by a heating step, although there is some debate about whether the heat shock step is critical for the uptake of DNA (Chen et al. 2001; Kimoto and Taketo, 2003). When E. coli is subjected to a temperature of $42^{\circ} \mathrm{C}$, a set of genes called the heat shock genes are expressed, which enable the bacteria to survive at such temperatures. However, at temperatures above $42^{\circ} \mathrm{C}$, the bacteria's ability to uptake DNA becomes reduced, and at more extreme temperatures the bacteria will die. Although not essential, a heat shock can increase the transformation efficiency. Van der Rest (Van der Rest et al. 1999) described the use of a heat shock following electroporation to induce highly efficient transformation of wild-type Corynebacterium glutamicum with xenogeneic plasmid DNA. Although Chen (Chen et al. 2001) proposed a convenient and rapid method for the genetic transformation of Escherichia coli with plasmids, the heat shock step was omitted and the resulting transformation efficiency is about 100 fold lower. 


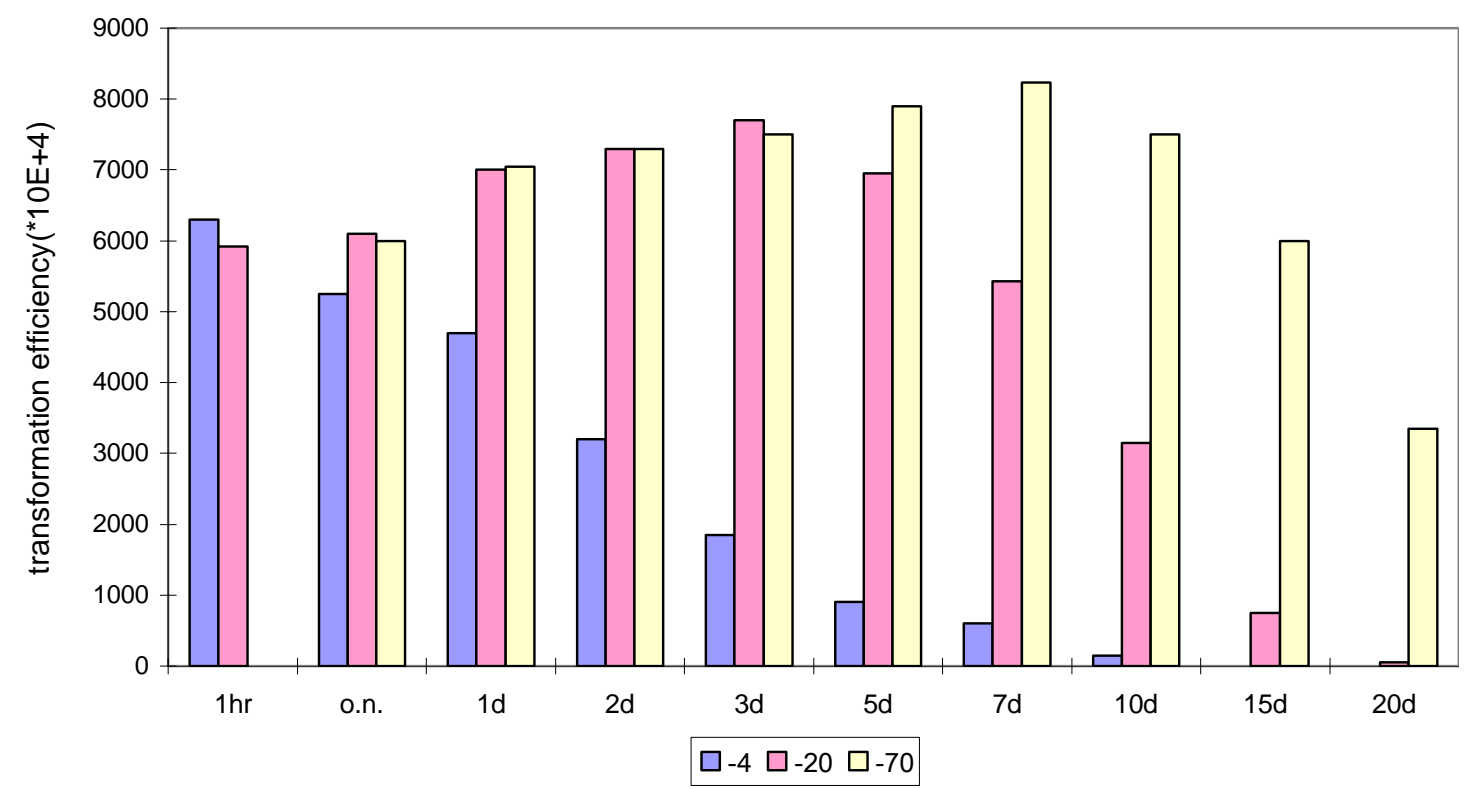

Figure 4. Effect of competent cell storage time at different temperature on transformation efficiency (XL1 blue, pAHC25, normal transformation method).

\section{ACKNOWLEDGMENTS}

The authors would like to thank Prof. Peter Shewry at Rothamsted Research (UK), for his helpful discussions and Professor Caroline Sparks at Rothamsted Research (UK), for her critical reading and correcting of the manuscript. We are grateful to our families, colleagues and students for their support of this work.

\section{REFERENCES}

BRIAN, P. and HELER, M.K. High efficiency 5 min transformation of E. coli. Nucleic Acids Research, 1996, vol. 24, no. 3, p. 536-537.

COHEN, S.N.; CHANG, A.C.; BOYER, H.W. and HELLING, R.B. Construction of biologically functional bacterial plasmid in vitro. National Academy of Sciences of the Unites States of America, 1973, vol. 70, no. 11, p. 32403244.

CHEN, X.; GUO, P.; XIE, Z. and SHEN, P. A convenient and rapid method for genetic transformation of E. coli with plasmids. Antonie Van Leeuwenhoek, 2001, vol. 80, no. 34, p. 297-300.

DAGERT, M. and EHRLICH, S.D. Prolonged incubation in calcium chloride improves the competence of $E$. coli cells. Gene, 1979, vol. 85, no. 6, p. 23

FIERRO, F.; LAICH, F.; GARCIA-RICO, R. and MARTIN, J.F. High efficiency transformation of Penicillium nalgiovense with integrative and autonomously replicating plasmids. International Journal of Food
Microbiology, January 2004, vol. 90, no. 2, p. 237-248.

INOUE, H., NOJIMA, H. and OKAYAMA, H. High efficiency transformation of Escherichia coli with plasmids. Gene, 1990, vol. 96, no. 3, p. 23-28.

HANAHAN, D.; JESSEE, J. and BLOOM, F.R. Plasmid transformation of Escherichia coli and other bacteria. Methods in Enzymology, 1991, vol. 20, no. 4, p. 63-113.

KIMOTO, H. and TAKETO, A. Efficient electrotransformation system and gene targeting in pyogenic streptococci. Bioscience, Biotechnology and Biochemistry, October 2003, vol. 67, no. 10, p. 2203-2209.

KURIEN, B.T. and SCOFIELD, R.H. Polyethylene glycolmediated bacterial colony transformation. Biotechniques, 1995, vol. 18, no. 6, p. 1023-1026.

MAEDA, S.; SAWAMURA, A. and MATSUDA, A. Transformation of colonial Escherichia coli on solid media. FEMS Microbiology Letters, July 2004, vol. 236, no. 1, p. 61-64.

MCCORMAC, A.C.; ELLIOTT, M.C. and CHEN, D.F. A simple method for the production of highly competent cells of Agrobacterium for transformation via electroporation. Molecular biotechnology, 1998, vol. 9, no. 2, p. 155-159.

OKAMOTO, A.; KOSUGI, A.; KOIZUMI, Y.; YANAGIDA, F. and UDAKA, S. High efficiency transformation of Bacillus brevis by electroporation. Bioscience, Biotechnology and Biochemistry, 1997, vol. 61, no. 1, p. 202-203. 
RYU, J. and HARTIN, R.J. Quick transformation in Salmonella typhimurium LT2, Biotechniques, 1990, vol. 8, no. 1, p. 43-44.

SAMBROOK, J.; FRITSCH, E.D. and MANIATIS, T. Molecular Cloning: A Laboratory Manual, Cold Spring Harbor: Cold Spring Harbor Laboratory Press, Plainview, NY, 1989, 2nd Ed. p. 49-55. ISBN:7-03-002808-2/Q.372 (Chinese).

TAKAHASHI, R.; VALEIKA, S.R. and GLASS, K.W. A simple method of plasmid transformation of $E$. coli by rapid freezing, Biotechniques, 1992, vol. 13, no. 5, p. 711-715.

TOPCU, Z. An optimized recipe for cloning of the polymerase chain reaction-amplified DNA inserts into plasmid vectors. Acta Biochimica Polonica, 2000, vol. 47, no. 3, p. 841-846.

TSEN, S.D.; FANG, S.S.; CHEN, M.J.; CHIEN, J.Y.; LEE, C.C. and TSEN, D.H. Natural plasmid transformation in Escherichia coli. Journal of Biomedical Science, 2002, vol. 9, no. 3, p. 246-252.

VAN DER REST, M.E.; LANGE, C. and MOLENAAR, D. A heat shock following electroporation induces highly efficient transformation of Corynebacterium glutamicum with xenogeneic plasmid DNA. Applied Microbiology and Biotechnology, 1999, vol. 52, no. 4, p. 541-545. 